\title{
Wyrok Sądu Metropolitalnego w Katowicach (c. Sobański) z 21.12.2004 z tytułu niezdolności powódki do podjęcia istotnych obowiązków małżeńskich
}

Ius Matrimoniale 10 (16), 227-230

2005

Artykuł został opracowany do udostępnienia w internecie przez Muzeum Historii Polski w ramach prac podejmowanych na rzecz zapewnienia otwartego, powszechnego i trwałego dostępu do polskiego dorobku naukowego i kulturalnego. Artykuł jest umieszczony w kolekcji cyfrowej bazhum.muzhp.pl, gromadzącej zawartość polskich czasopism humanistycznych i społecznych.

Tekst jest udostępniony do wykorzystania w ramach dozwolonego użytku. 


\section{Wyrok Sądu Metropolitalnego w Katowicach (c. Sobański) z 21.12.2004 z tytułu niezdolności powódki do podjęcia istotnych obowiązków małżeńskich}

\section{Przebieg sprawy:}

WH i AG zawarli małżeństwo 7.9.1985 w kościele parafialnym św. Barbary w D. Ważność tego małżeństwa zaskarżyła AG 13.2.2001 w Sądzie Biskupim w S. Sprawę prowadzono z tytułu przymusu po stronie powódki oraz z tytułu niezdolności do podjęcia istotnych obowiązków małżeńskich po stronie pozwanego, a także powódki. Dnia 31.7.2002 zapadł wyrok orzekający nieważność małżeństwa tylko - z tytułu niezdolności powódki. Po myśli k. 1682 \$1 sprawa znalazła się w Trybunale apelacyjnym. Trybunał ten dekretem z 29.11.2002 skierowal sprawę na drogę procesu zwyczajnego. Powódka wniosła o rozpatrzenie sprawy na stopniu apelacyjnym także z tytułu wywartego na nią przymusu. Dekretem z 10.2.2003 ustalono przedmiot sporu w formie pytania: czy udowodniono nieważność małżeństwa $z$ tytułu: 1) niezdolności do podjęcia istotnych obowiązków małżeńskich z przyczyn natury psychicznej po stronie powódki; 2) przymusu i ciężkiej bojaźni po stronie powódki. Dnia 20.2.2004 Trybunał orzekł, że nie udowodniono nieważności małżeństwa z żadnego $\mathrm{z}$ rozpatrywanych tytutów. Tym samym Trybunał zatwierdził wyrok Trybunału I instancji w części przeciwnej tezie powódki, uchylił natomiast w części orzekającej nieważność małżeństwa. Na prośbę powódki Najwyższy Trybunal Sygnatury Apostolskiej reskryptem z 29.5.2004 wyznaczył Sąd Metropolitalny w Katowicach do rozsądzenia sprawy w III instancji. Akta sprawy nadeszły 16.7.2004. Sprawę przyjęto do procesu 21.7.1004. Ponieważ powódka zwróciła się do Sądu o rozpatrzenie sprawy także z tyt. przymusu i bojaźni, zwrócono jej uwagę, że Sąd został upoważniony do rozsądzenia sprawy jedynie z tytułu jej niezdolności do podjęcia istotnych obowiązków malżeńskich. Pismem z 20.8.2004 poinformowano powódkę, że może wnieść do Najwyższego Trybunału Sygnatury Apostolskiej o upoważnienie tut. Sądu do rozpatrzenia sprawy 
także $\mathrm{z}$ tytułu przymusu (co miałoby sens jedynie przy przedłożeniu nowych dowodów), może też (jak to zapowiedziała w piśmie z 6.4.2004 do Trybunału apelacyjnego) wnieść apelację do Trybunału Roty Rzymskiej (względnie też - co oczywiste - zaakceptować rozpatrywanie sprawy przez Sąd zgodnie z mandatem Najwyższego Trybunału Sygnatury Apostolskiej). Pismem z 2.9.2004 powódka zwróciła się „o prowadzenie sprawy zgodnie z obowiązującymi zasadami i aktami”. Powódka nie przedłożyła nowych wniosków dowodowych, pozwany nie zareagował na pisma Sądu. Dekretem z 6.9.2004 zamknięto postępowanie. W dniu dzisiejszym Sąd orzekł jak następuje:

\section{Prawny i faktyczny stan sprawy:}

1. Normy prawa mające zastosowanie w rozpatrywanej sprawie wyłożono w wyrokach poprzednich Instancji i nie zachodzi potrzeba powtarzania ich.

2. W piśmie z 2.9.2004 powódka uznaje za przykry dla niej i niezrozumiały fakt, że do ,złożonych” przez nią i finansowanych spraw „nagle w jakimś momencie" jej - nie zgłaszający się, jak twierdzi, do Sądu, nie uczestniczący w żadnych rozprawach i nie interesujący się procesem - „byly mąż” składa zarzut jej niezdolności. Istotnie, prośbę o prowadzenie sprawy także z tytułu niezdolności powódki do podjęcia istotnych obowiązków małżeńskich przedłożył pozwany w trakcie przesłuchania w Sądzie I instancji (wbrew twierdzeniu powódki uczestniczył więc w procesie w I instancji). Powódka przyjęła 30.5.2001 rozszerzenie tytułów nieważności do wiadomości. Jeszcze w trakcie procesu w I instancji powódka, zaznajomiwszy się z opinią biegłej o pewnych cechach niedojrzałości, wyraziła „nadzieję, iż ten fragment wypowiedzi dotyczy (jej) niedojrzałości na dzień zawarcia związku małżeńskiego, przez co działała pod przymusem”. Innego rozumienia swej niedojrzałości powódka nie dopuszcza. We wzmiankowanym już piśmie z 2.9.2004 powódka informuje: „Moja niezdolność do podjęcia istotnych obowiązków małżeńskich odnosi się do przymusu i bojaźni po mojej stronie, co determinowało moje postawy i zachowania, nie zaś do poważnych zaburzeń psychoemocjonalnych". Myśl powódki wiążącej niezdolność i bojaźn pozostaje niejasna. Można ją rozumieć jako niezdolność - tylko i wylącznie - do przeciwstawienia się matce czy też niezdolność jako skutek przymusu. W pierwszym przypadku 
nie mogłaby być przedmiotem obecnie rozpatrywanej sprawy, dotyczylaby bowiem kwestii nieważności z tytułu przymusu, dwukrotnie już rozstrzyganej i leżącej poza kompetencją Sądu. W drugim przypadku pytanie procesowe brzmiałoby, czy oddziaływanie matki było tak silne i głębokie, że wypaczyło osobowość powódki powodując niezdolność do nawiązania wspólnoty małżeńskiej. Odpowiedź na to pytanie musi wypaść negatywnie. Wprawdzie powódka twierdzi, że załamana nie uczestniczyła w przygotowaniach, ale sama mówi o sobie, że uważała i uważa się za zdolną do małżeństwa. Niezrozumiałe jest ustalenie Trybunału I instancji, wedle którego „Zależność emocjonalna od matki w okresie kojarzenia małżeństwa uniemożliwiały jej wyrażenie przedmiotu zgody małżeńskiej”. Ta zależność miałaby wynikać z ,groźby utraty więzi rodzinnych", co byłoby „determinantą psychiczną". Trzeba tu jednak zauważyć, że groźby mogły ewent. wpływać na decyzję małzeńską, nie widać, jak moglyby uniezdalniać powódkę do funkcjonowania w małżeństwie. Trudno dostrzec związek przyczynowy między podnoszonymi przedślubnymi groźbami i zdolnością ( $z$ natury rzeczy poślubną) do wykonywania obowiązków małżeńskich. Sąd podziela ocenę materialu dowodowego dokonaną przez Trybunal II instancji: nie ma w nim podstaw do stwierdzenia, aby powódka była niezdolna do podjęcia istotnych obowiązków małżeńskich.

3. Skoro powódka przesłala Sądowi kopię swego pisma skierowanego 6.4.2004 do Trybunału II instancji, Sąd czuje się zmuszonym stwierdzić, iż uważa za zbędne zawarte w nim pouczanie, że sądy powinny „w sposób logiczny bez kierowania się swoimi ambicjami czy emocjami przeanalizować w sposób indywidualny wszelkie przesłanki, w oparciu o które małżeństwo można uznać za zawarte w sposób nieważny". W rozpatrywanej sprawie nie ma przesłanek nieważności małżeństwa z racji niezdolności psychicznej powódki i żadna analiza logiczna nie prowadzi do takiego wniosku. Powódka zdaje sobie z tego sprawę, wszak sama kwestionowała ten tytuł nieważności, a potem usiłowała stworzyć nową konstrukcję prawną. Sąd docenia starania powódki o uregulowanie własnej sytuacji kanonicznej, ale musi też poważnie traktować zasadę nierozerwalności małżeńskiej. Na orzeczenie Sądu nie mogą wpływać poślubne fakty dokonane, Sąd może orzekać jedynie opierając się na faktach procesowo udowodnionych, przydatnych dla zbudowania przesłanki tezy procesowej, w tym przypadku: nieważności małżeństwa z tytułu niezdolności powódki do podjęcia obowiązków małżeńskich. Jako wyznaczony do rozpatrzenia konkretnego 
przypadku Sąd musi działać w granicach udzielonego mandatu. Sąd zwrócil 20.8.2004 powódce uwagę na formalne aspekty sprawy i wyłożył istniejące możliwości proceduralne. Powódka zadecydowała jak to wyżej już wspomniano, jednak w żadnym ze swych pism nie przytacza argumentów za nieważnością małżeństwa z tytułu jej - powodowanej przyczynami natury psychicznej - niezdolnością do podjęcia istotnych obowiązków małżeńskich.

Wobec takiego stanu sprawy Sąd orzeka, że nie udowodniono nieważności małżeństwa z tytułu niezdolności powódki do podjęcia istotnych obowiązków małżeńskich i - tym samym - zatwierdza wyrok Trybunału II instancji w częśsi orzekającej z tegoż tytułu. 